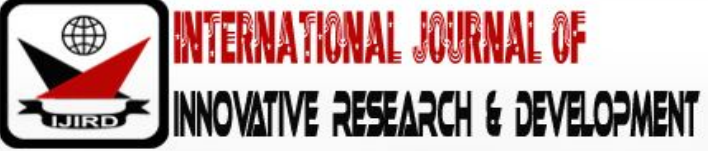

ISSN 2278 - 0211 (Online)

\section{Cultural Imperatives of Women Leadership Role in Nigeria}

\author{
Dr. Olupona, Adeola Moromoke \\ Principal Lecturer, Department of General Studies, Polytechnic Ibadan, Nigeria \\ Olalere, Kunle Oluwafemi \\ Lecturer, Department of General Studies, Polytechnic Ibadan, Nigeria
}

\begin{abstract}
:
Nigerian women have been known in the course of history, to have played important roles in national development and the emancipation of their societies despite the existence of cultural limitations. The age-long diatribe that seeks to create a matrix of social and cultural disaffection for women has however intensified and institutionalized patriarchy. By propagating a monologue that describes women as weaklings and irrelevant in the emerging post-colonial social contraption, the importance of women in leadership roles has been permanently eroded. This paper therefore, contends that all prejudicial conceptions about the inability of women in leadership positions are misplaced and untenable. It combines an historic and sociological approach in affirming the cogency of the womenfolk in national development. It also submits that there is the need to create cultural incentives aimed at enhancing the roles of women in national development.
\end{abstract}

Keywords: Women leadership roles, cultural limitation, national development, governance, women empowerment

\section{Introduction}

The monologic discourse on the difficulty of women to attain prime leadership roles in the academia and the society at large has populated various academic discussions. The discourse is not unconnected with the patriarchal nature of the African society and the predominant view that whatever good a woman does is mostly anomalous. In most cultures of the world the womenfolk are often relegated within the social construct based on allusions to their feminine nature. Some other researches have premised their submission on the Judeo-Christian account of the role of woman in the damnation of mankind in the Garden of Eden.

It is noteworthy to state here that the intention of this paper is not to amplify the catalogue of articles and discourses on the denigration of women in leadership roles but to make a case for women by highlighting the place of women in history and how they have played positive roles in the course of human civilisation. It also projects the argument that it is unfair to utilise the Judaeo-Christian thesis on Eve in the condemnation of the womenfolk while projecting all the ills patriarchy to as viable reasons for treating women as less than capable when matters of the state are to be discussed.

Ibitokun (1995:116) comments:

The second-fiddle player role allocated to females in the Christian West has, in great part, its genesis in the Judaeo-Christian belief in which woman, as the descendant of the 'Criminal' Eve, should be ignored and set aside when serious issues related to the governance of the state are to be discussed.

Arising from the aforementioned, it is pertinent to state that despite the existence of many myths utilised to suppress and oppress women, various nations and tribes of the world have recorded women of achievement and substance. This argument will form the basis of our discussion in this paper.

\section{Nigerian Women in Leadership Roles: The Past Records}

The argument that women have made their quota towards the development and substance of the corporate existence of Nigerian cannot be faulted. Apart from being the central figure at the home front, women have made their laudable contribution towards the social, political, educational and economic development of the nation. Thus, the myth of women incompetence and irrational thinking is misdirected and unfair. Even, the creation of Nigeria was by a woman, Miss Flora Shaw (later known as Mrs. Flora Lugard), on January 8th, 1897.

Nigeria is blessed with women of enviable achievements. Virtually all ethnic groups and cultures of Nigeria have women who had made laudable contributions towards the advancement of their land and the people. Moremi of Ile-Ife, for instance, is a (wo)man-hero that sacrificed her (wo)manity and only child in order to liberate Ile-Ife from attacks of the Igbo. If not for the nationalist spirit, Ile-Ife would have been run down by the Igbo marauders. Ile-Ife was liberated but women-folks are still in the bondage of the patriarchal society. In order to liberate her society, she lost her cultural space 
as a mother and as a wife. Other Nigerian women or substance that had used their influence to uplift their societies were Madam Tinubu of Lagos/ Abeokuta, Emotan of Bini Kingdom, Aminat of Zaria. These women at different periods in Nigerian history protected their lands from total collapse.

In most Yoruba towns and cities, there were and there are still some chieftaincy titles meant for women. Among these chieftaincy titles were Iyalode (mother/ head of women), Iyaloja/ Iyalaje (head of market women) of these two titles, Iyalode gains much recognition and acceptance. Unfortunately, the office of Iyalaje/ Iyaloja has been encroached by the egoist males. Today, it is not uncommon in Nigerian cultural discourses to hear titles such as Babalaje/ Baba Oja. This is an attempt by the egocentric male society at deconstructing the female hegemony in the country's major towns and cities.

Before and after independence, particularly in Ibadan, the office of Iyalode had been a formidable one. The office has been a sole preserve of women of substance - wealth and political in the society. The Iyalode line constitutes the fourth line in the Ibadan chieftaincy, following the Olubadan, Balogun and Seriki lines (Denzer, 1998:5). Like the kings in Yorubaland, Iyalode performs civil, religious and arbitrative roles in the land. Denzer (Opcit: 6) observes:

The duties of the Ibadan Iyalodes consisted of acting as an intermediary between the townsmen and the male hierarchy, supervision of the market system, generally looking after women's welfare, and arbitrating disputes between women or between a man and his wife, unless it was so contentious that it had to be submitted to the Olubadan for settlement. She also acted as custodian of women imprisoned for theft, trade malpractices and marital offences.

In carrying out these responsibilities, Iyalode commands much respect because of her social status, wealth and military prowess. Johnson (1978:77) accounts for the reason for the extreme power of most Iyalodes in Yorubaland. He writes:

The Iyalode, i.e. the queen of the ladies is a title bestowed upon the most distinguished lady in the town. Some of these Iyalodes command a force of powerful warriors, and have a voice in the council of the chiefs. Through the Iyalode, the women of the town can make their voices heard in municipal and other affairs.

For various social and political factors, the office of Iyalode was waxing stronger. This is not unconnected with the line of sub-chiefs that assist(ed) Iyalode in her administrative and political functions. In Yorubaland, particularly in Ibadanland, the hierarchy of Iyalode office is given as: Iyalode; Otun Iyalode; Balogun Iyalode; Osi Iyalode; Asipa Iyalode; Iyalaje; Ekerin Iyalode; Ekarun Iyalode; Abese Iyalode; Maye Iyalode; Asiwaju Iyalode and Ekefa Iyalode. All these hierarchies are pointers to the fact that within cultural matrix, women perform leadership roles. Despite the various praiseworthy roles played by various Iyalodes in community services, they faced antagonism from the male hegemony as in the case of Efunsetan Aniwura and Aare Latosa.

Apart from chieftaincy titles meant for women in the traditional Yoruba societies, women have also functioned as regents. The use of regency in Yorubaland does not ascribe full rights to the woman-regent. A woman-regent has her rights denied and her cultural and civil privileges undermined. Dasylua (2010:5) unequivocally complains about how the rights of a woman-regent are undermined. He writes:

For example, whereas a regent, by tradition, may have the powers of an Oba (king), she is denied the right to be married, or have children of her own while her 'reign' lasts. But a substantive monarch can have many wives and many children as he desires. Again, besides the paraphernalia that goes with a regent's position, she must always dress in men's attires. In other words, she is denied her full rights to womanhood. By implication, her femininity and identity are subsumed under a non-negotiable phallocentric space.

These cultural encumbrances that limit the rights of women in the traditional Yoruba/ Nigerian societies still persist today. A woman is not always allowed to have a full control of the rein of power.

In the religious arena, the leadership role of a woman cannot be ignored. In most traditional cultures of Nigeria, woman served as carriers during any rites of passage as in the case of Arugba Osun. This is not unconnected with Ogundipe's (2007:29) observation that:

As the woman is sacred in endogenous thought, her body is also sacred. Similarly, her body as the house of life, parts of her body such as her hair and nail clippings, women's discharges such as her milk, menses, tears, sweat, and even saliva are considered sacred. They can and are used as blessings, curses and potions for power-social, material and supernatural.

Sadly, the assumed sacredness of women body is an attempt to limit their opportunities and rights within a phallocentric space. As part of conspiracy against the leadership role of women, standards are set for whoever becomes the priestess of a god or a carrier during the rites of passage - the right candidate must be a virgin or a woman in a menopausal stage.

It is high time Nigerian government learnt from the past mistakes when all the other fifteen principal gods of Yorubaland conspired against Osun because she was a woman. Things were not moving smoothly until the Supreme Being, Olodumare instructed them that the inclusion of Osun in the affairs of the Universe would bring peace. Thus, in our contemporary Nigerian society, women should be empowered to show their potentials for leadership role within a sociocultural milieu. It is however contended in this paper, in consonance with the opinion of Dukor (2003:84) that women empowerment is not changing women from what they are but to remove cultural and social shackles that have inhibited their development.

\section{Some Nigerian Women: The Present Realities}

The undeniable fact is that Nigerian women are humans. Thus, the social expectations of vanguard of human rights and gender equality are the fact that: 
- Women bodies should be honoured and free from all sorts of humiliation, dehumanization and dewomanization by men;

- Women should have the same socialization process as men;

- Women should have the same political rights as men;

- Women should be allowed leadership within a political space.

In contemporary Nigerian politics, the exclusionary stance of Nigerian leaders, particularly about the capability of Nigerian women for leadership is premised upon the opinion of Aristotle, a Greek Philosopher that 'male is more fitted to rule than the female'. This is a pointer to the fact that the perceived and lived marginalization of women from leadership role is as old as man. Pateman and Shanely (1991:9-10) queries the status quo. They write:

Wrong done to women has been this systematic exclusion of women from taking part in and as full members and citizens of the polity in political debates deliberations and contests.

The marginalization of women from leadership role can be corrected if women are given chance to operate on the same political terrains as men based on the principles of fairness, equity and justice. This will afford women the opportunities of utilizing their potentials in the redemption of the Nigerian society. Ebijuwa (2000:39) established that:

The significance of this is that when everybody participates in the decision-making process, under a condition of equal advantage; the decision reached eliminate the whole question of the marginalization and subordination of women.

Thus, fairness, equity and justice should be the hallmark of the Nigerian democratic governance.

In the current political dispensation, women have more political leadership roles to play unlike during the military interregnum in the country. At least, in the contemporary democratic governance, there are about $30 \%$ of leadership roles assigned for women as deputy governors, senators, members of House of Representatives, ministers, commissioners and heads of parastatals. This laudable practice gives women more opportunities to demonstrate their leadership qualities in a country that has been traumatised by male inactions in the pattern of corruption and misappropriation of national funds. These myriads of problems, economic, political, social and religious have tended to give the impression that nothing is working in Nigeria (Osuntokun, 2002:13).

Like Oliver Twist, in recent time, women made a call through the national dailies that $40 \%$ of the leadership positions in the country should be reserved for them. This is not a fowl cry but the male oligarchy in the corridor of power will not want their phallic ego challenged. In various capacities, Nigerian women leaders and politicians have proved their worth and dependable leaders and administrators. The laudable contribution of Okonjo Iweala at ensuring that Nigeria got a debt relieve cannot be forgotten in the country's history. Professor Dora Akunyili will not be forgotten for combating issues of fake drugs and other consumables. She devotedly served her motherland at her own risk and that of her family. As a woman, the current Chairman of Economic and Financial Crime Commission (EFCC), Mrs Waziri has not experienced any scandal against her personality and office. There is, however, a ray of hope in the emerging women leaders and women politicians in Nigeria, notwithstanding the recent 'scandal', if at all, that forced the House of Representatives' Speaker, Mrs Patricia Ette, out of office (Dasylua, 2010:11). The critic (Dasylua, Opcit) therefore warns that:

Aspiring women leaders and women politicians need to intervene now by renegotiating existing political space with their male counterparts and as such engage in active leadership role both at the local and national level, failure of which the current male-dominated political class may unwittingly plunge the country further into a deeper political crisis.

This renegotiation of existing political space does not mean disruption of culture. Women empowerment does not mean creation of gender crisis that can plunge the nation into the state of anarchy and socio-political confusion.

The outstanding success of women in the contemporary democratic governance is actually expected. Within a cultural matrix, particularly in the traditional setting, women have been functioning as warriors as in the case of Idahomi Warriors, administrators and mediators as in the case of Madam Tinubu and liberators of a race or people as in the case of Moremi among others. It can therefore be said that women have come of age in Nigerian leadership roles.

\section{Recommendations}

- This paper recommends that there should be certain cultural incentives that put in place with the singular aim of revoking all prejudicial notions against women. It should include the eradication of stereotypes that present women as a 'weaker vessel' when compared to men.

- It also recommends that government should ensure that women are accorded the opportunity to take up at least 45 per cent of available positions in government as a way of building their capacity and confidence in a society where they are often regarded as incompetent.

- The paper affirms the historical role of women in social development and it recommends that a rejuvenation of those roles through a form of sensitisation and public enlightenment will serve as a veritable impetus for women in modern societies.

- The paper also recommends the establishment of a well-structured and institutionalised programme where the girl child is trained and raised to build and enhance leadership traits to complement their conventional education.

- The paper recommends that a proper synergy between the womenfolk in leadership positions will further complement the roles of men and all other contributors in the development of the Nigerian state. 


\section{Conclusion}

Using the historical and sociological approaches this paper underscores the point that women have the same social and political space in Nigeria. From the traditional society to the present time, women have been playing important roles in the sustenance of societal and cultural ideals. Thus, the phallocentric society should not denigrate women. This paper is not advocating female domination of Nigerian politics and polity. The paper, however, contends that Nigerian women should be given ample opportunities to demonstrate their latent abilities to lead the country towards better achievements. After all, seeing is believing and experience is the best teacher.

Finally, women have done it and they can still do more. Thus, societal prejudice against the matriarchs should be displaced to ensure sustainable national development in Nigeria.

\section{References}

i. Dasylua, A. (2010): Politics of Development: Interrogating Phallocentric Space, Renegotiating the Gender of Modern Nigerian Politics. A paper presented at Africa Conference, Texas U.S.A.

ii. Denzer, L. (1998): The Iyalode in Ibadan Politics and society, c. 1850-1997. Ibadan: Humanities research Centre.

iii. Dukor, M. (2003): 'How not to empower women', in Dukor Maduabuchi (ed.) Philosophy and Politics: Discourse on Values, Politics and Power in Africa. Lagos: Malthouse Press Limited.

iv. Ebijuwa, T. (2000): 'Rethinking women's Empowerment in abortion Discourse in Africa', in Current Viewpoint: A Review of Culture and Society, vol. 2, nos. 1 and 2.

v. Ibitokun, B. M. (1995): African Drama and the Yoruba world view. Ibadan: Ibadan University Press.

vi. Johnson, S (1978): A History of the Yoruba: from the Earliest Times to the Beginning of the British Protectorate. Lagos: C.M.S Bookshop.

vii. Ogundipe, M. (2007): Indigenous and Contemporary Gender Concepts and Issues in Africa: Implications for Nigeria's Development. Lagos: Malthouse Press Limited.

viii. Osuntokun, J. (2002): Democracy and the Nigeria Populace: What dividends. Ibadan: THE HOUSE, U.I.

ix. Pateman, C. and Shanely, M

x. L. (1991) 'Introduction', in Feminist Interpretation and Political Theory. Oxford: Polity Press. 